\title{
Centesimal composition and bioactive compounds in fruits of buriti collected in Pará
}

\author{
Composição centesimal e de compostos bioativos em frutos de buriti coletados no Pará
}

\author{
Luciana Ribeiro Trajano MANHÃES ${ }^{1 *}$, Armando Ubirajara Oliveira SABAA-SRUR ${ }^{2}$
}

\begin{abstract}
The link between diet and the incidence of chronic and degenerative diseases has already been established. The foods that play a role in preventing and/or treating these diseases are called functional foods. Buriti can be highlighted amongst these foods since it is an excellent source of vegetable oil, which is rich in $\beta$-carotene and oleic acid. This research evaluated the potential of the pulp of this fruit as a functional food focusing on its incorporation to the diet. Buriti pulp presented $62.93 \%$ moisture, $8.25 \%$ total carbohydrates, and $2.10 \%$ protein. The lipid fraction corresponded to $13.85 \%$, and oleic acid was the main fatty acid. It also contained $0.94 \%$ total mineral content. Based on the results obtained, it can be said that the pulp of buriti may contain bioactive compounds with functional activities, but further research is needed to assess such potential.
\end{abstract}

Keywords: buriti; Mauritia flexuosa; functional food; oleic acid; carotenoids; antioxidant substances.

\section{Resumo}

Hoje já se sabe da relação entre a alimentação e a incidência e/ou prevenção de certas doenças crônicas não transmissíveis. Os alimentos que desempenham a função de prevenir e/ou tratar essas doenças são conhecidos como alimentos funcionais. Dentre esses alimentos, destaca-se o buriti, que é uma excelente fonte de óleo vegetal rico em $\beta$-caroteno e ácido oleico. Essa pesquisa visou avaliar a potencialidade funcional da polpa desse fruto, com vista a sua incorporação na alimentação. A polpa de buriti apresentou 62,93\% de umidade, 8,25\% de carboidratos totais, $2,10 \%$ de proteína bruta. A fração lipídicacorrespondeu a 13,85\%, tendo o ácido oleico como principal ácido graxo dessa fração. Dispõe ainda de $0,94 \%$ de minerais totais, com destaque para o teor de selênio. O estudo revelou ainda o poder antioxidante dessa polpa, em função dos resultados de carotenoides, polifenóis totais e ácido ascórbico. Em função dos resultados encontrados, conclui-se que a polpa de buriti possui indícios de conter compostos bioativos com atividades funcionais, necessitando de estudos in vivo para comprovar sua ação.

Palavras-chave: buriti; Mauritia flexuosa; alimentos funcionais; ácido oleico; carotenoides; antioxidantes.

\section{Introduction}

The link between diet and the incidence of some diseases, such as coronary heart diseases, non-insulin dependent diabetes mellitus, and different types of cancer is already well-known. Diet is also recognized, as part of a healthy lifestyle, and it has a fundamental role in the prevention and treatment of those diseases. A classical example is the association between the animal saturated fats intake and the occurrence of colon, prostate, and breast cancer. Diets rich in vegetables and fruits are associated to the reduction in the occurrence of some types of cancer including lung, colon, esophagus, and stomach cancer. Although the mechanisms associated with the reduction of the incidence of these diseases are still not completely clarified, it is known that these diets are usually poor in saturated fats and rich in fibers and various vitamins and minerals. The foods which either prevent or minimize chronic and degenerative diseases, in addition to their role to a good nutrition, are called functional foods (POURCHET-CAMPOS, 1998). They have drawn the public opinion attention due to the health benefits they bring. Indeed, they have been the focus of many studies on foods in great research centers world-wide (PARK; KOO; CARVALHO,
1997). This definition started in Japan, current functional foods world leader and owner of specific regulation in regard to this type of products (CRAVEIRO; CRAVEIRO, 2003). Currently, it has got spread to the United States and European countries, where there are no specific regulations yet (AMERICAN..., 2004). The process of regulation of these foods in Brazil occurred only in 1999, which is late when compared with other countries (SOUSA; SOUSA NETO; MAIA, 2003).

In the Amazon region, an area of highly concentrated plant biodiversity, sources such as the Buriti (Mauritia flexuosa, Mart.) with innumerable functional properties can be found. However, great part of those sources is still unknown. Buriti is the fruit and the palm tree from the Arecaceae family (SALAY, 2005), common in the Northern region of Brazil (FERRI, 1980). It grows well in low flooded fertile valleys (PALLET, 2002). Even though it is known in regions where it appears, there is little data in the literature on its pulp's nutritional value. The lipid content is an excellent vegetable oil source, rich in $\beta$-carotene and oleic acid, as well as tocopherols and palmitic acid in lower concentrations (ALBUQUERQUE et al., 2003).

\footnotetext{
Received 12/8/2009

Accepted 20/7/2010 (004331)

Food Technology of the Institute of Technology, Departament of Food Tecnology - DTA, Federal Rural University of Rio de Janeiro - UFRRJ, DTA, BR 465, Km 7,

CEP 23890-000, Seropédica, RJ, Brazil,e-mail: lucianartmanhaes@gmail.com

${ }^{2}$ IN-DNBE, Federal University of Rio de Janeiro - UFRJ, CCS Building, Block J, $2^{\text {nd }}$ floor, Rio de Janeiro, RJ, CEP 21949-900, Brazil

* Corresponding author
} 
According to the Brazilian Institute of Geography and Statistics, the Buriti production in Brazil in 2000 was of $381 \mathrm{t}$. This production was used fully to obtain fibers (INSTITUTO..., 2005) to produce strings, cloths, fish nets, and hammocks, but the fruits were not used (ENGEL, 1975). Such waste is relevant since a buriti palm tree can produce between $150-200 \mathrm{~kg}$ of fruits per harvest (MARTIN, 1990).

Therefore, this work aimed to evaluate by analytical determinations, the centesimal composition and bioactive compounds of the buriti pulp providing nutritional information about it that can be an incentive to industries to commercialize the raw fruit or candies, jellies, ice creams, nectars, color agents, and antioxidants. These products can be part of the dietary habits to prevent or minimize the incidence of certain diseases with low cost production.

\section{Materials and methods}

Fresh ripe and ready-to-eat buriti fruits, with uniform size and shape, were harvested in Marituba, Pará state, Brazil, in December 2005. Fruits with $16.00 \pm 0.29 \mathrm{~cm}$ circumference and $50.6876 \pm 1.1342 \mathrm{~g}$ average weight were packed on the same day of harvest and sent, in a refrigerated box for perishable products, by flight to Rio de Janeiro city, Rio de Janeiro state, Brazil. $12 \mathrm{~h}$ after leaving Belém, capital of Pará state, the fruits were brought to the Food Analysis and Processing laboratory at Federal Rural University of Rio de Janeiro, where they were checked out, washed under running water, and depulped. The pulp was packed in various high density oxygen barrier polyethylene bags, which after being hermetically sealed were stored at $-20^{\circ} \mathrm{C}$ until analysis. During the depulping process, the processing plant artificial lighting was turned off in agreement with the International Vitamin A Consultive Group (IVACG) recommendations as described by Arroyane et al. (1982).

Prior to the analytical determinations, the pulps were defrosted, homogenized, and discarded after analysis. All determination analysis were carried out in triplicate $(n=3)$.

Moisture content was determined gravimetrically in an oven at $105^{\circ} \mathrm{C}$ until a stable weight was reached (INSTITUTO..., 2005). The results were shown in grams of moisture per $100 \mathrm{~g}$ of the sample.

The extraction of the lipid fraction was carried out in accordance to the methodology described by Bligh e Dyer (1959). The results were shown in grams of total lipids per $100 \mathrm{~g}$ of the sample.

For the determination of the total fatty acids, the samples were submitted to cold extraction of the lipid fraction using the Bligh e Dyer (1959) method followed by saponification and methylation. Fatty acid esters were determined in a CG Chrompack CP9001 (FID) gas chromatograph, equipped with a CP - Sil 88 FAME fused silica WCOT $0.2 \mu \mathrm{m} \times 50 \mathrm{~m} \times 0.25 \mathrm{~mm}$ capillary column (Chrompack catalog n.7488), operating under the following conditions: temperature of the injector $=250{ }^{\circ} \mathrm{C}$; temperature of the detector (FID) $=250{ }^{\circ} \mathrm{C}$; column initial temperature $=160^{\circ} \mathrm{C}(32$ minutes $)$, with rise of $3{ }^{\circ} \mathrm{C}$ per minute until $200{ }^{\circ} \mathrm{C}$; column final temperature $=200{ }^{\circ} \mathrm{C}$ (30 minutes); split of 1:100; carrier gas $=$ hydrogen, at $70 \mathrm{KPa}$; and injected sample quantity $=0.2 \mu \mathrm{L}$. Each sample was injected only once (HUANG; WANG; CRENSHAW, 2006). The results were expressed as the fatty acid composition in total lipid content.

The total nitrogen determination was carried out using the Kjeldahl method (ASSOCIATION..., 1995). Total protein was calculated by multiplying the total nitrogen by 6.08 , the conversion factor calculated from the amino acid total sample. The results were expressed in grams of total proteins per $100 \mathrm{~g}$ of the sample.

In order to determine the amino acid profile, after hydrolysis with $\mathrm{HCl} 6 \mathrm{M}$, the samples were analyzed by chromatography with fluorimetric detection after derivatization with 6-aminoquinolyl-N-succinimidyl carbamate using an amino acid auto-analyzer, Beckman, model 7300, equipped with a $200 \mathrm{~mm}$ length column containing a sodium ionic exchange resin. The Total tryptophan, methionine, and cysteinewere not determined. Those values were obtained from the ENDEF Food Composition Table (INSTITUTO..., 1999) (SPACKMAN et al., 1958). The results were converted to wet basis and expressed in grams of amino acid. $100^{-1} \mathrm{~g}$ of pulp.

Total Monosaccharide, disaccharide, and starch were determined by the Somogy method adapted by Nelson (1944), in which anhydrous glucose was adopted as standard monosaccharide. Total dietary fiber contents (TDF) were determined by the nonenzymatic-gravimetric method, according to Li e Cardoso (1994), with results expressed in grams of the corresponding carbohydrate $100^{-1} \mathrm{~g}$ of sample. The total carbohydrate content was obtained by adding the contents of monosaccharides, disaccharides, starch, and fibers present in the sample expressing the sum in grams of total carbohydrates. $100^{-1} \mathrm{~g}$ of sample.

Total ash content was determined by previous carbonization of the dry samples followed by incineration in a muffle furnace at $550{ }^{\circ} \mathrm{C}$ (INSTITUTO..., 2005). The results were expressed in grams of total ash. $100^{-1} \mathrm{~g}$ of sample.

The total mineral content was determined from dry samples calcinated in a muffle furnace at $550^{\circ} \mathrm{C}$ from a minimum period of $2 \mathrm{~h}$ followed by acid digestion (HCL 2 mol.L $\mathrm{L}^{-1}$ ) and analysis by mass spectrophotometry with a plasma inductively connected in the semi-quantitative mode using a Perkin Elmer-Sciex ELAN 6000 equipment (ASSOCIATION..., 1995). The results were converted to wet basis and expressed in milligrams of the corresponding mineral. $100^{-1} \mathrm{~g}$ of sample.

The Total Energetic Value (TEV) was calculated using the traditional conversion factors for proteins $\left(4 \mathrm{kcal}_{\text {gram }}{ }^{-1}\right)$, lipids $\left(9 \mathrm{kcal} . g r a m^{-1}\right)$, and carbohydrates $\left(4 \mathrm{kcal} . g r a m^{-1}\right)$, according to Lehninger (1986). The results were expressed in $\mathrm{kcal} \cdot 100^{-1} \mathrm{~g}$ sample.

With regard to the analysis of carotenoids, the samples were submitted to lipid extraction and saponification steps. The present carotenoids separation and identification was done by high performance liquid chromatography (HPLC) operating under the following conditions: mobile phase: gradient of t-butyl methanol/methyl ether - 80:20 to 10:90 in 28 minutes; 
flow: $0.8 \mathrm{~mL} /$ minute; detector: Photodiode Array (DAD) 300 $550 \mathrm{~nm}$; column: C30 $3 \mu \mathrm{m} \times 250 \mathrm{~mm}-$ YMC Carotenoid waters; temperature of the column: $30^{\circ} \mathrm{C}$; and injected sample volume: $0.2 \mu \mathrm{L}$, one injection for each sample (RODRIGUEZAMAYA; KIMURA, 2001). All analysis steps were conducted protected from light and the carotenoid extract was covered with aluminum foil. The peaks identification was done by comparison with the carotenoids retention times from the standard used, which presented peaks for violaxanthin, lutein, zeaxanthin, $\beta$-cryptoxanthin, $\beta$-carotene, and $\alpha$-carotene and lycopene. The results were expressed in milligrams of $\beta$-carotene. $100^{-1} \mathrm{~g}$ of the sample and milligrams of $\alpha$-carotene $100^{-1} \mathrm{~g}$ of sample since other carotenoids were not found in significant amounts. The determination of total carotenoids was carried out from the same procedure described above in the extraction of carotenoids followed by Hitachi-U 3200 spectrophotometer readings using a wave length of $449 \mathrm{~nm}$ (RODRIGUEZ-AMAYA; KIMURA, 2001). The results were converted to wet basis and expressed in milligrams of total carotenoids. $100^{-1} \mathrm{~g}$ of sample.

Ascorbic acid was determined by the method of Tillman (INSTITUTO..., 2005) modified by Benassi e Antunes (1988), who used oxalic acid as solvent in substitution of metaphosphoric acid. The results were expressed in milligrams of ascorbic acid. $100^{-1} \mathrm{~g}$ of sample.

Total polyphenols were determined by the Folin-Denis method described by the AOAC (ASSOCIATION..., 1995), in which tannic acid was adopted as standard polyphenol. The results were expressed in milligrams of tannic acid. $100^{-1} \mathrm{~g}$ of sample.

\section{Results and discussion}

The moisture content in the centesimal composition of buriti pulp deserves attention on account of being the major component of the pulp with the value of $62.93 \pm 0.12 \mathrm{~g} \cdot 100^{-1} \mathrm{~g}$ of pulp (Table 1). Nevertheless, it was lower than the value determined by Mariath, Lima and Santos (1989) of 69.6\% and lower than $71.70 \%$, value reported on the Food Composition Table (INSTITUTO..., 1999) of the National Study of Family Expenditure (ENDEF). The research of Mariath, Lima and Santos (1989) was carried out in the Federal University of Paraíba, a region close to an abundant Buriti growing area. The fruits used in their study were probably harvested and immediately analyzed, while those in the present study were harvested, cooled, and frozen which could have favored moisture loss, a factor that could have changed the final moisture content.

Total lipids, the centesimal composition second greatest component, was of $13.85 \pm 0.69 \mathrm{~g} \cdot 100^{-1} \mathrm{~g}$ of pulp (Table 1 ), value higher than those described by Mariath, Lima and Santos (1989) and those of ENDEF Food Composition Table (INSTITUTO..., 1999) 8.10 and $11.00 \%$ respectively. Apart from a probable dehydration of the fruits during transportation and storage, the methodologies used may have been different, which could possibly have caused the differences in the results presented. The Buriti lipid concentration must be valued for its oil and fat, which are the main energy sources for the human body and have been used by industries due to their abilities to dissolve flavor and aromatic compounds to modify various products consistency (FRANCA et al., 1999).

Regarding the unsaturated fatty acids in the pulp, linoleic $(2.69 \%)$ and linolenic acid $(2.17 \%)$ were present in lower amounts than oleic acid (73.33\%) (Table 2), which contains a double bond on carbon 9, known as an omega-9 fatty acid, and have a basic role in hormone synthesis in the human organism and in the reduction of blood LDL cholesterol levels (GALVÃO, 2000; TURATTI, 2000). Similarly, linoleic and linolenic fatty acids, compounds of the omega- $6(\mathrm{C} 18: 2, \mathrm{n}-6)$ and omega-3 (C18:2, n-3) families, respectively (DOMINIONI; DIONIGI, 1987), also play important roles in the human organism since they are part of the cell membrane and have antithrombotic and anti-inflammatory activities, since they act as antithrombotic prostaglandin and leukotriene precursors and stimulate immunity, respectively, besides being related to the reduction of coronary heart disease and its risk factors (CHIARELLO; RIOS; PEREIRA, 2005).

Amongst the saturated fatty acids, palmitic acid (C16:0) was predominant, corresponding to $19.31 \%$ (Table 2), which is in accordance with the literature, but it is one of the villains in blood cholesterol increase (HARTMAN, 1993).

The values of the fatty acids found in this research are similar to those found by Franca et al. (1999) and Albuquerque et al. (2003) (Table 2).

It is important to point out that one of the oils that is most widely used in the human diet, which has great appeal as a healthy food, is olive oil, which contains $72.50 \%$ oleic acid in its lipid fraction. Buriti oil, presenting higher levels of this fatty acid (73.32\%), until the present moment has not yet been incorporated into the habitual diet, perhaps due to lack of incentive of its production in an industrial scale or

Table 1. Centesimal composition of buriti pulp (g.100-1 g sample).

\begin{tabular}{lr}
\hline Analysis & Average \pm s.d. \\
\hline Moisture & $62.93 \pm 0.12$ \\
Lipids & $13.85 \pm 0.69$ \\
Proteins & $2.10 \pm 0.19$ \\
Monosaccharides & $1.29 \pm 0.00$ \\
Disaccharides & $0.11 \pm 0.16$ \\
Starch & $1.68 \pm 0.07$ \\
TDF & $5.17 \pm 1.16$ \\
Total ash & $0.94 \pm 0.06$ \\
TEV & 166.36 \\
\hline s.d. $=$ standard deviation. TEV $=$ Total Energetic Value. TDF $=$ Total Dietary Fiber.
\end{tabular}

Table 2. Fatty acid composition of buriti pulp oil (\%).

\begin{tabular}{lr}
\hline Fatty acid & Average \pm s.d. \\
\hline Caprilic (C8:0) & $0.59 \pm 0.13$ \\
Palmitic (C16:0) & $19.31 \pm 0.13$ \\
Stearic (C18:0) & $1.86 \pm 0.03$ \\
Oleic (C18:1 c) & $73.32 \pm 0.10$ \\
Linoleic (C18:2 c) & $2.69 \pm 0.12$ \\
Linolenic (C18:3 c) & $2.17 \pm 0.03$ \\
\hline
\end{tabular}

s.d. $=$ standard deviation. $\mathrm{c}=$ cis. 
little data disclosure. Another oil which is also widely used in the prevention of coronary heart disease is canola oil, which contains about $23.60 \%$ less of this fatty acid if compared to buriti oil.

Buriti pulp oil contains approximately four times more linolenic acid (C18:2, n-3) and about one third the quantity of linoleic acid (C18:2, n-6) than olive oil. Canola oil presents higher values of both acids when compared to the oil analyzed in this study; however, it must be considered that canola oil is generally used in foods submitted to heating and therefore, depending on the time and temperature of the process applied, undesirable alterations in the chemical structures of these fatty acids may occur, which will reduce their benefits to human health. The same does not occur with the fatty acids of buriti oil, which is mostly consumed raw and is probably be better used by the organism.

Literature discloses that this pulp contains higher levels of palmitic acid when compared to olive oil, which contains $11 \%$, and to canola oil, which contains $4 \%$. A proteina do buriti The protein present in buriti was named flexuonin after the name of the species, Mauritia flexuosa, as well excelcin, named after Brazil nut (Berthollecia excelsa, HBK) protein and glicenin after soy (Glycine max, L.) protein. In the present study, The buriti protein content was $2.10 \mathrm{~g} \pm 0.19 \mathrm{~g} \cdot 100^{-1} \mathrm{~g}$ pulp (Table 1 ), which is higher than that found by Mariath, Lima and Santos (1989), 1.8\%, and lower than the value in the ENDEF Food Composition Table (INSTITUTO..., 1999), which was $2.6 \%$. This higher value can be attributed to the conversion factor used in the ENDEF Food Composition Table, which was 6.25 and to the total nitrogen content, which was $0.41 \mathrm{~g} \cdot 100^{-1} \mathrm{~g}$ pulp.

Although buriti is not considered a protein source, buriti pulp protein can be considered a vegetable protein of excellent quality due to the high concentrations of sulfur amino acids (methionine + cysteine), aromatic amino acids (phenylalanine + tyrosine), and tryptophan, when compared to the FAO reference protein, considering that these amino acids are usually limiting in proteins of vegetable origin (SABAASRUR, 1976).

Attention must be drawn to the high content of total aromatic amino acids found in this study, which was $16.64 \mathrm{~g} \cdot 100^{-1} \mathrm{~g}$ protein (Table 3), representing $277.33 \%$ of the necessity of these amino acids to compose a reference protein, which is surprising given their importance for premature children, who need tyrosine to guarantee nitrogen retention and maintain normal plasmatic levels (SHILS et al., 2003). Another surprise disclosed by the total amino acid was the high content of tryptophan, $2.38 \mathrm{~g} \cdot 100^{-1} \mathrm{~g}$ protein, which accounts for approximately $238 \%$ of the composition of the reference protein established by Food... (1985). It is also of extreme importance since it is a precursor of serotonin, a powerful vasoconstrictor found in blood plasma, besides being a stimulant of gastrointestinal activities (CUQ; FRIEDMAN, 1989) and a niacin precursor, reducing the requirements of this vitamin if it is present in the diet. Sulfur amino acid contents were also surprising since they account for $230 \%$ of the amount determined by Food... (1985) for the reference protein, which is of fundamental importance in the human diet since methionine acts as the main donator of methyl
Table 3. Essential amino acid total of buriti pulp and comparison to the reference protein established by FAO (FOOD..., 1985).

\begin{tabular}{lccc}
\hline $\begin{array}{c}\text { Essential amino } \\
\text { acid (AA) }\end{array}$ & $\begin{array}{c}\text { g AA/100 g reference } \\
\text { protein }^{1}\end{array}$ & $\begin{array}{c}\text { g AA/100 g } \\
\text { flexuonin }\end{array}$ & $\begin{array}{c}\text { Limiting } \\
\text { AA }\end{array}$ \\
\hline Histidine & - & 1.90 & \\
Isoleucine & 4 & 1.42 & $2^{\text {nd }}$ \\
Leucine & 7.00 & 2.38 & $1^{\text {st }}$ \\
Lysine & 5.50 & 1.90 & $1^{\text {st }}$ \\
Methionine & - & - & \\
Cysteine & - & - & \\
Total sulfur AA & 3.50 & 8.08 & \\
Phenylalanine & - & - & \\
Tyrosine & - & - & \\
Total aromatic AA & 6.00 & 16.64 & \\
Threonine & 4.00 & 8.55 & \\
Tryptophan & 1.00 & 2.38 & \\
Valine & 5.00 & 1.90 & $3^{\text {rd }}$ \\
\hline${ }^{1}$ FAO (FOOD..., 1985). AA $=$ amino acid. & & \\
& & & \\
& & & \\
& & &
\end{tabular}

groups for the synthesis of various compounds such as choline and creatine, and cysteine guaranteeing the nitrogen supply necessary for premature babies (SHILS et al., 2003). However, buriti protein does not completely fulfill the requirements for an ideal reference protein as stipulated by FAO (FOOD..., 1985) since some essential amino acids are limiting. Amongst them, leucine and lysine can be considered as first-limiting amino acids followed by isoleucine, and the third-limiting amino acid is valine (Table 3). Nevertheless, the concentrations of these amino acids must not be neglected since they can greatly contribute to the human diet because once added to the essential amino acids of other foods ingested in the diet they can supply the quantities determined by the reference protein according to FAO (FOOD..., 1985).

When comparing the contents of the essential amino acids in flexuonin with the estimates of the requirements of these nutrients as suggested by FAO (FOOD..., 1985), it can be observed that the consumption of $0.5 \mathrm{~kg}$ of buriti pulp/day, by an adult weighing $70 \mathrm{~kg}$ on average, supplies approximately $1 / 4$ of the daily requirements of histidine, isoleucine, leucine, lysine, total sulfur amino acids, and valine besides supplying one third of the estimated requirements of tryptophan and half the requirements of total aromatic amino acids and threonine, which can be considered excellent for a vegetable protein.

The content of total carbohydrates in buriti pulp was $8.25 \mathrm{~g} \cdot 100^{-1} \mathrm{~g}$ pulp (Table 1), lower than the values found in the study of Mariath, Lima and Santos (1989) and on the ENDEF Food Composition Table (INSTITUTO..., 1999), which were $19.80 \%$ and $13.10 \%$, respectively. This can be justified by the fact that these data were obtained by adding the contents of moisture, total ash, proteins, and lipids of raw buriti pulp and subtracting them from 100, while in our study this content was determined analytically by a high precision spectrophotometric method, in agreement with Silva et al. (2003).

Amongst the carbohydrates, dietary fibers certainly deserve to be highlighted, due to their scientifically demonstrated functional properties (RAUPP et al., 2002), since their presence 
in foods is of great interest to health. In addition, numerous studies have related the role of dietary fiber with the prevention of certain diseases such as colon cancer, obesity, cardiovascular problems, and diabetes (MEYER et al., 2000). The starch content (1.68\%) found in the sample (Table 1), made it possible to adopt the methodology used to determine total dietary fiber, which resulted in $5.17 \pm 1.16 \mathrm{~g} \cdot 100^{-1} \mathrm{~g}$ pulp, lower than the value of the ENDEF Food Composition Table (INSTITUTO..., 1999), which is $7.6 \%$. This can be justified by possible differences in the methodologies used. If the guidelines of the American Dietetic Association (1993) for adults, which recommend the ingestion of a diet rich in carbohydrates, low in fats and with around 20-30 g/day fibers, considered as excellent values for the prevention of colon cancer, are followed, the consumption of $100 \mathrm{~g}$ of buriti pulp is capable of supplying approximately $20 \%$ of this daily recommendation, fact that must be considered given its contribution to the prevention of innumerable diseases.

Regarding the total mineral content of buriti pulp, the value of $0.94 \pm 0.06 \mathrm{~g} \cdot 100^{-1} \mathrm{~g}$ pulp (Table 1) was found, which is closer to the value found by Mariath, Lima and Santos (1989), of $0.70 \%$, than to that of the ENDEF Food Composition Table (INSTITUTO..., 1999), of $1.60 \%$, result that is probably related to differences in the centesimal composition in the different studies since the methodology used to determine total ash in the pulp of this fruit was possibly the same in all studies.

Buriti pulp presents some minerals in considerable amounts, which is extremely important since they act as cofactors in various metabolic reactions in the human organism. Amongst the macrominerals presented in Table 4, potassium (218 mg.100 $10{ }^{-1} \mathrm{~g}$ pulp) is found in highest concentration in the pulp. This element is very important for its involvement in vital physiological functions, such as the osmotic and acid-base balances and intra and extracellular concentrations related to the $\mathrm{Na} / \mathrm{K}$ pump system (MAHAN; ESCOTT-STUMP, 2002). The second highest mineral concentration in this pulp is attributed to calcium ( $80.49 \mathrm{mg} \cdot 100^{-1} \mathrm{~g}$ pulp), relevant in the prevention of bone problems, such as osteoporosis in adults and rachitism in children, since low calcium consumption is a potential problem in Brazil (VANNUCCHI et al., 1990). Magnesium (40.34 mg.100 $10 \mathrm{~g}^{-1} \mathrm{~g}$ pulp) is the third highest concentration of the minerals in the pulp and must be considered due to its importance in organic functions. It is co-factor of more than 300 metabolic enzymes and participates in fatty acid and protein synthesis reactions and in the phosphorilation of glucose and its derivatives in the glicolytic pathway, besides playing a role in neuromuscular transmission and activity (BESSMERTNY et al., 2002). Sodium (11.25 mg.100 $10{ }^{-1} \mathrm{~g}$ pulp), as the fourth greatest component of the mineral content, must be considered since it also operates in the osmotic and acid-base balances (SHILS et al., 2003) although it can cause health problems, such as hypertension, when ingested in high quantities.

Within the universe of microminerals (Table 4), the highest concentration found in buriti pulp was that of iron $\left(1.77 \mathrm{mg} \cdot 100^{-1} \mathrm{~g}\right.$ pulp) followed by zinc $\left(0.60 \mathrm{mg} \cdot 100^{-1} \mathrm{~g}\right.$ pulp) and subsequently by copper $\left(0.15 \mathrm{mg} \cdot 100^{-1} \mathrm{~g}\right.$ pulp$)$. Iron deficiency anemia has a high incidence in women and children in developing countries (NOGUEIRA et al., 1998), which emphasizes the importance of the presence of this mineral in the pulp studied. Zinc is essential because it is a co-factor for more than 100 enzymes and participates in diverse metabolic processes such as cellular growth and multiplication, cicatrization, and macrophage and lymphocyte functioning (MARET, 2001). Copper is essential as well due to its performance in various metabolic functions such as the mobilization of iron for hemoglobin synthesis, besides being a component of various enzymes such as cytochrome C-oxidase, superoxide dismutase, and monoamine-oxidase (FRANCO, 1995). The presence of these minerals in buriti pulp enriches the nutritional value of this food even more.

Amongst the trace elements known, iodine, manganese, chromium, and selenium were present in the pulp. The presence of iodine is fundamental importance in the prevention of endemic goiter (SHILS et al., 2003). Selenium, a powerful antioxidant substance, can be essential for delaying aging, relieving pre-menstrual tension, preserving tissue elasticity, preventing cancer, and neutralizing free radicals. Manganese is important since the deficiency of this mineral can lead to sterility, notable bone abnormalities, and ataxia in the offspring of mothers with manganese deficiency (WAITZBERG, 2002). The presence of chromium in the pulp is of great nutritional value since this mineral potentizes the action of insulin thus influencing carbohydrate, lipid, and protein metabolism (SHILS et al., 2003).

Aluminum, rubidium, strontium, nickel, titanium, cesium, and barium were also found in buriti pulp; however, the true

Table 4. Comparison of the total mineral content of buriti pulp with the dietary recommendations (NATIONAL..., 1989) for men/women aged 25-50 years, respectively.

\begin{tabular}{|c|c|c|c|}
\hline Minerals & $\begin{array}{c}\text { Average } \pm \text { s.d. } \\
\left(\mathrm{mg} 100 \mathrm{~g}^{-1} \text { sample }\right)\end{array}$ & $\mathrm{RDA}^{1}$ & $\begin{array}{l}\% \text { daily } \\
\text { requirements }\end{array}$ \\
\hline \multicolumn{4}{|l|}{ Macrominerals } \\
\hline Potassium (K) & $218.00 \pm 12.26$ & - & - \\
\hline Calcium (Ca) & $80.49 \pm 4.37$ & $800 / 800 \mathrm{mg} /$ day & $10 \%$ \\
\hline Sodium (Na) & $11.25 \pm 0.46$ & - & - \\
\hline Magnesium (Mg) & $40.34 \pm 1.98$ & $350 / 280 \mathrm{mg} /$ day & $13 \%$ \\
\hline \multicolumn{4}{|l|}{ Microminerals } \\
\hline Iron $(\mathrm{Fe})$ & $1.77+0.03$ & $10 / 15 \mathrm{mg} /$ day & $10 \%$ \\
\hline Copper $(\mathrm{Cu})$ & $0.15+0.01$ & $1.5-3.0 \mu \mathrm{g} /$ day & $100 \%$ \\
\hline Zinc $(Z n)$ & $0.60+0.02$ & $15 / 12 \mathrm{mg} /$ day & $5 \%$ \\
\hline \multicolumn{4}{|l|}{ Trace minerals } \\
\hline Chromium (Cr) & $0.12+0.01$ & $50-200 \mu \mathrm{g} /$ day & $100 \%$ \\
\hline Manganese (Mn) & $1.79+0.07$ & $2-5 \mathrm{mg} /$ day & $100 \%$ \\
\hline Selenium (Se) & $0.03+0.01$ & $70 / 55 \mu \mathrm{g} /$ day & $50 \%$ \\
\hline Iodine (I) & $7.47+2.15$ & $150 / 150 \mu \mathrm{g} /$ day & $100 \%$ \\
\hline Aluminum (Al) & $0.21+0.02$ & - & - \\
\hline Rubidium (Rb) & $0.69+0.03$ & - & - \\
\hline Strontium (Sr) & $0.14+0.01$ & - & - \\
\hline Nickel (Ni) & $0.06+0.00$ & - & - \\
\hline Titanium (Ti) & $0.05+0.00$ & - & - \\
\hline Cesium (Cs) & $0.02+0.00$ & - & - \\
\hline Barium $(\mathrm{Ba})$ & $0.13+0.02$ & - & - \\
\hline
\end{tabular}

${ }^{1}$ Nacional Research Council (1989), s.d. $=$ standard deviation. 
function of these elements in human metabolism is still not well elucidated in the available literature.

Mineral elements are extremely related to human health and diseases since their deficiency or excess can induce physiological changes in individuals (GIBSON, 1989). From the public health point of view, it is important to assure the population that the ingestion of all nutrients is adequate to a normal diet. At the same time, the diet must not contain toxic elements above acceptable levels, preventing chemical poisoning.

If the bioavailability of these minerals is not considered, $100 \mathrm{~g}$ of the pulp can supply $10 \%$ of the calcium and $13 \%$ of the magnesium required. Copper complies with the recommendation for this mineral, whereas iron complies with approximately $10 \%$ and zinc only $5 \%$. Chromium, manganese, and iodine, comply fully with the requirements, whereas selenium complies with approximately $50 \%$ of the daily requirements, both for men and women.

The knowledge of the total energy value (TEV) of foods is of great interest for the nutrition field since it makes it possible to know the calories ingested by the consumer. Therefore, the present study determined that the total energy value (TEV) of $100 \mathrm{~g}$ of buriti pulp corresponds to $166.36 \mathrm{kcal}$, close to the value on the ENDEF Food Composition Table, which is $144.00 \mathrm{kcal}$ (INSTITUTO..., 1999) (Table 1).

Regarding carotenoids, the results shown in Table 5 indicate that buriti pulp contains $23.26 \mathrm{mg}$ total carotenoids. $100^{-1} \mathrm{~g}$ pulp. The main carotenoids in buriti pulp were $\beta$-carotene, which has $100 \%$ pro-vitamin activity (GROSS, 1991) and corresponds to $60 \%$ of the total carotenoids present in the sample (13.71 mg.100-1 g pulp) and $\alpha$-carotene, which has $53 \%$ pro-vitamin activity (GROSS, 1991) and corresponded to 6\% of the total carotenoids present in the sample $\left(1.47 \mathrm{mg} \cdot 100^{-1} \mathrm{~g}\right.$ pulp). The data found by Godoy e Rodriguez-Amaya (1994) for $\alpha$-carotene and $\beta$-carotene were much higher than those found in this study, which can be explained by possible oxidation of the sample analyzed since the determination was not carried out immediately after harvest. However, the buriti pulp studied presented more $\beta$-carotene than carrot and kale (Brassica sylvestris, L.), which are considered the main sources of this carotenoid in human diet. The fact that carotenoids exert many functions, for example, antioxidant activity and vitamin A precursor, makes this result of utmost importance for human life since this fruit could be used for the prevention of various diseases, amongst them eyesight problems caused by vitamin A deficiency, diseases that result from oxidative stress, such as cancer, amongst others.

Ascorbic acid has various functions which are based mainly on its property as a reversible biological reducing agent. Thus, it is essential as a co-factor for various biochemical reactions and as a protective antioxidant that works in the aqueous phase, which can be regenerated in vivo when oxidized; it also affects a variety of factors associated to the risk of heart disease, including the integrity of vascular tissue, vascular tonus, lipid metabolism, and blood pressure (HORROBIN, 1996). It can also increase non-heme iron absorption and participate in the formation of collagen (RONCHETTI et al., 1996). The
Table 5. Contents of nutrients high in antioxidant activity present in buriti pulp, expressed in $\mathrm{mg} \cdot 100^{-1} \mathrm{~g}$ sample.

\begin{tabular}{cc}
\hline Antioxidant substances & Average \pm s.d. $\left(\mathrm{mg} .100^{-1} \mathrm{~g}\right)$ \\
\hline$\alpha$-carotene & $1.48 \pm 0.09$ \\
$\beta$-carotene & $13.71 \pm 0.75$ \\
Total carotenoids & $23.36 \pm 0.98$ \\
Polyphenols & $9.47 \pm 3.06$ \\
Ascorbic acid & $56.90 \pm 2.56$ \\
\hline
\end{tabular}

s.d. $=$ standard deviation.

results showed that the ascorbic acid contents in the buriti pulp (56.90 mg.100 $100^{-1} \mathrm{~g}$ pulp) (Table 5) are close to the values found in orange (50-100.00 mg.100-1 g orange) (ANDRADE et al., 2002) and are much lower than those found in Brussels sprouts (Oleracea brassica, L.) (90-150.00 mg.100-1 g Brussels sprouts). These two foods are considered sources of vitamin C. However, when considering the high contents of this antioxidant substance in Brussels sprouts, it is important to highlight that buriti is generally consumed raw, while Brussels sprouts are normally submitted to thermal processes before consumption that speed up the loss of this vitamin since it is unstable to heat.

Like ascorbic acid, polyphenols also have antioxidant activity and, based on their antioxidant function, these compounds possess anti-atherosclerotic, anti-inflammatory, antitumor, antithrombotic, anti-osteoporosis and antiviral activities (NIJVELDT et al., 2001). This research evidenced that $100 \mathrm{~g}$ of buriti pulp contained $9.46 \pm 3.06 \mathrm{mg}$ of total polyphenols, value higher than that found in the literature for carrot and Brussels sprouts (CUNHA, 2005) (Table 5). This characteristic is of great relevance to human health given its relationship with the prevention of diseases caused by oxidative stress, amongst others, as previously mentioned.

It can be concluded that in addition to its antioxidant properties conferred by its contents of selenium, polyphenols, ascorbic acid and carotenoids, the pulp of buriti contains bioactive compounds with functional activities due to the high concentrations of oleic acid and carotenoids and for being a great source of vegetable protein. However, further studies are necessary to confirm the beneficial effects of those functional substances.

\section{References}

ALBUQUERQUE, M. L. S. et al. Infrared absorption spectra of Buriti (Mauritia flexuosa L.) oil. Vibrational Spectroscopy, v. 33, p. 127131, 2003. http://dx.doi.org/10.1016/S0924-2031(03)00098-5

AMERICAN DIETETIC ASSOCIATION - ADA. Position of the American Dietetic Association: Health Implications of Dietary Fiber. Journal of the American Dietetic Association, v. 93, p. 14461447, 1993. http://dx.doi.org/10.1016/0002-8223(93)92252-S

AMERICAN DIETETIC ASSOCIATION - ADA. Position of the American Ditetic Association: Functional Foods. Journal of the American Dietetic Association, v. 104, n. 5, p. 814-826, 2004. PMid:15127071. http://dx.doi.org/10.1016/j.jada.2004.03.015

ANDRADE, R. S. G. et al. e distribuição de ácido ascórbico em três frutos tropicais. Eclética Química, v. 27, n. special São Paulo, 2002. 
ARROYANE, G. et al. Biochemical methology for assesment of Vitamin A Status. Washington: International Vitamin A Consultive Group - IVACG, The Nutrition Foundation, 1982.

ASSOCIATION OF OFFICIAL ANALYTICAL CHEMISTS - AOAC. Official methods of analysis of the Association of Official Analysis Chemists. Arlington: AOAC, 1995. 957 p.

BENASSI, M. T.; ANTUNES, A. J. A comparison of metaphosphoric and oxalic acids as extractants solutions for the determination of vitamin $C$ in selected vegetables. Arquivos de Biologia e Tecnologia, v. 31, n. 4, p. 507-513, 1988.

BESSMERTNY, O. et al. A randomized clinical trial of nebulized magnesium sulfate in addition to albuterol in the treatment of acute mild-to-moderate asthma exacerbations in adults. Annals of Emergency Medicine, v. 39, p. 585-591, 2002. PMid:12023699. http://dx.doi.org/10.1067/mem.2002.123300

BLIGH, E. G.; DYER, W. J. A rapid method of total lipid extraction and purification. Canadian. Journal Biochemistry and Physiology, v. 37, n. 8, p. 911-917, 1959. http://dx.doi.org/10.1139/o59-099

CHIARELLO, R. J.; RIOS, C. E.; PEREIRA, S. E. Avaliação subjetiva global de crianças de 1 a 4 anos de idade durante suplementação diária com fonte alimentar vegetal de Ômega-3. Revista do Instituto de Ciências da Saúde, v. 23, n. 1, p. 25-34, 2005.

CRAVEIRO, A. A.; CRAVEIRO, A. C. Alimentos Funcionais: A Nova Revolução. Fortaleza: UFC-PADETEC, 2003. 282 p.

CUNHA, A. L. P. Determinação da composição centesimal, fibra insolúvel e polifenóis em horatliças antes e após diferentes processamentos térmicos. 2005. $78 \mathrm{f}$. Dissertação (Mestrado em Nutrição Humanas)-Universidade Federal do Rio de Janeiro, Rio de Janeiro, 2005.

CUQ, J. A.; FRIEDMAN, M. Effect of heat on tryptophan in food: chemistry, toxicology and nutritional consequences. In: FRIEDMAN, M. Absorption and utilization of amino acids III. Florida: CRC Press, 1989. p. 103-28.

DOMINIONI, L.; DIONIGI, R. Immunological function and nutritional assesmnt. Journal of Parenteral and Enteral Nutrition, v. 11, p. 705-725, 1987. PMid:2444725. http://dx.doi. org/10.1177/014860718701100509

ENGEL, J. (Org.). Underexploited Tropical Plants with Promising Economic Value. Washigton: National Academy of Sciences, 1975. p. 133-137.

FERRI, M. G. Vegetação brasileira. Belo Horizonte: Itatiaia, 1980. 157 p.

FRANÇA, L. F. et al. Supercritical extraction of carotenoids and lipids from buriti (Mauritia flexuosa), a fruit from the Amazon region. Journal of Supercritical Fluids, v. 14, p. 247-256, 1999. http:// dx.doi.org/10.1016/S0896-8446(98)00122-3

FRANCO, G. Tabela de Composição de Alimentos. 9. ed. Rio de Janeiro: Atheneu, 1995. 307 p.

FOOD AND AGRICULTURE ORGANIZATION OF THE UNITED NATIONS - FAO; WORLD HEALTH ORGANIZATION - WHO; UNITED NATIONS UNIVERSITY - UNU. Energy and Protein Requeriments. Geneva: WHO, 1985. 65 p. Report of a Joint FAO/ WHO/UNU. Expert Consultation. (Technical Reports Series, n. 724).

GALVÃO, L. P. Novos ingredientes funcionais e seus benefícios para a saúde do século XXI. Food Ingredients, n. 9, p. 21, 2000.

GIBSON, R. S. Assessment of trace element status in humans. Progress in Food and Nutrition Science, v. 13, p. 67-111, 1989.

GODOY, H.; RODRIGUEZ-AMAYA, D. B. Ocurrence of cis-isomers of provitamin A in Brasilian Fruits. Journal of Agricultural and Food
Chemistry, v. 42, p. 1306-1313, 1994. http://dx.doi.org/10.1021/ jf00042a011

GROSS, J. Pigments in vegetables: Clorophyls and Carotenoid. Nova York: Avy Books, 1991.

HARTMAN, L. A evolução de idéias sobre a função dos óleos e gorduras na alimentação humana. Palestra. Boletin SBCTA, v. 27, n. 1, p. 55-58, 1993.

HORROBIN, D. F. Ascorbic acid and prostaglandin synthesis. In: HARRIS, J. R. (Ed.). Subcellular biochemistry. Ascorbic acid: biochemistry and biomedical cell biology. New York: Plenum Press, 1996. v. 5, p. 109-115.

HUANG, Z.; WANG, B.; CRENSHAW, A. A. A simple method for the analysis of trans fatty acid with GC-MS and ATe-Silar-90 capillary column. Food Chemistry, v. 98, p. 593-598, 2006.

INSTITUTO ADOLFO LUTZ - IAL. Normas Analíticas do Instituto Adolf Lutz. Métodos químicos e físicos para análise de alimentos. 4. ed. Brasília: Ministério da Saúde, 2005. 1018 p.

INSTITUTO BRASILEIRO DE GEOGRAFIA E ESTATÍSTICA IBGE. Estudo Nacional da Despesa Familiar - ENDEF. Tabelas de Composição de Alimentos. 5. ed. Rio de Janeiro: IBGE, 1999.

INSTITUTO BRASILEIRO DE GEOGRAFIA E ESTATÍSTICA IBGE. Quantidade e valor dos produtos de extração vegetal e da sivicultura. Rio de Janeiro: IBGE, 2000. Disponível em: <www.ibge. gov.br>. Acesso em: 08 abr. 2005.

LEHNinger, A. L. Princípios de Bioquímica. Sarvier: São Paulo, 1986. $211 \mathrm{p}$.

LI, B. W.; CARDOZO, M. S. Nonenzymatic-gravimetric determination o dietary fiber in fruits and vegetables. Journal of AOAC International, v. 77, n. 3, p. 687-689, 1994.

MAHAN, L. K.; ESCOTT-STUMP, S. K. Alimentos, Nutrição \& Dietoterapia 10. ed. São Paulo: Roca, 2002. 1157 p.

MARET, W. Zinc biochemistry, physiology and homeostasis: recent insights and current trends. Bio Metal, v. 14, p. 187-90, 2001.

MARIATH, J. G. R.; LIMA, M. C. C.; SANTOS, M. P. Vitamin A of Buriti (Mauritia vinifera Mart) and its effectiveness in treatment and prevention of xerophtalmia. American Journal of Clinical Nutrition, v. 49, p. 849-853, 1989.

MARTIN, F. W. Perenial Edible Fruits of the Topics. Kansas City: United Departament of Agriculture, 1990.

MEYER, K. A. et al. Carbohydrates dietary fiber and incident type 2 diabetes in older womem. American Journal of Clinical Nutrition, v. 71, p. 921-930, 2000.

NATIONAL RESEARCH COUNCIL - NRC. Recommended Dietary Allowances. 10th ed. Washigton: National Academy Press, 1989.

NELSON, N. A fotometric adaptation of Somogy method for the determination of glucose. Journal of Biological Chemistry, v. 153, p. 375-380, 1944.

NIJVELDT, R. J. et al. Flavonoids: a review of probable mechanisms of action and potential application. American Journal of Clinical Nutrition, v. 74, n. 4, p. 418-425, 2001.

NOGUEIRA, N. N. et al. Estado nutricional de adolescentes grávidas suplementadas com ferro, zinco e pacido fólico. In: CONGRESSO BRASILEIRO DE CIÊNCIA E TECNOLOGIA DE ALIMENTOS, 1., 1998, Rio de Janeiro, Anais... Rio de Janeiro, 1998.

PALLET, D. Perspectiva de valorização dos frutos amazônicos obtidos por extrativismo. In: COLÓQUIO SYAL, 2002, Montpellier. Anais... Montpellier, 2002.

PARK, Y. K.; KOO, M. H.; CARVALHO, P. O. Recentes progressos dos alimentos funcionais. Boletim SBCTA, v. 31, n. 2, p. 200-206, 1997. 
POURCHET-CAMPOS, M. A. Um século de progresso em nutrição e alimentos. Boletim SBCTA, v. 32, n. 1, p. 1-10, 1998

RAUPP, D. S. et al. Propiedades funcionais-digestivas e nutricionais da polpa refinada de maçã. Scientia Agricola, v. 57, n. 3, 2002.

RODRIGUEZ-AMAYA, D. B.; KIMURA, M. Harvestplus Handbook for Carotenoid Analysis. Washington: International Food Policy Research Institute, 2001. 74 p.

RONCHETTI, I. P.; QUAGLINO JUNIOR, D.; BERGAMINI, G. Ascorbic acid and connective tissue. In: HARRIS, J. R. (Ed.). Subcellular biochemistry. Ascorbic acid: biochemistry and biomedical cell biology. New York: Plenum Press, 1996. v. 25, p. 249-64.

SABAA-SRUR, A. U. O. Processamento de castanha-do-Brasil (Bertholletia excelsa, H,B. K.). 1976. 59 f. Dissertação (Mestrado em Tecnologia de Alimentos)-Faculdade de Engenharia de Alimentos, Universidade Estadual de Campinas, Campinas, 1976.

SALAY, E. (Org.). Composição de Alimentos: Uma aborgadem multidisciplinar. Campinas: Núcleo de Estudos e Pesquisa em Alimentação, 2005.
SHILS, M. E. et al. Tratado de Nutrição Moderna na Saúde e na Doença. 9. ed. São Paulo: Manole, 2003. v. 1, 1026 p.

SILVA, R. N. et al. Comparação de métodos para a determinação de açúcares redutores e totais em mel. Ciência e Tecnologia de Alimentos, v. 23, n. 3, p. 337-341, 2003.

SOUSA, P. H. M.; SOUSA NETO, M. A.; MAIA, G. A. Componentes funcionais nos alimentos. Boletin SBCTA, v. 37, n. 2, p. 127-135, 2003

SPACKMAN, D. H.; STEIN, W. H.; MOORE, S. Automatic recording apparatus for use in the chromatography of amino acids. Analytical Chemistry, v. 30, n. 7, p. 1190-1206, 1958. http://dx.doi.org/10.1021/ ac60139a006

TURATTI, J. M. Óleos vegetais como fonte de alimentos funcionais. Food ingredients, p. 52, 2000.

VANNUCCHI, H. et al. (Ed.). Aplicação das recomendações nutricionais adaptadas à população brasileira. Ribeirão Preto. Ribeirão Preto: Editora Legis Suma, 1990. (Caderno de Nutrição, Sociedade Brasileira de Alimentação e Nutrição, v. 2).

WAITZBERG, D. L. Nutrição Oral, Enteral e Parenteral na Prática Clínica. 3. ed. São Paulo: Editora Atheneu, 2002. p. 131-134. 